$\begin{array}{lllllllllllllll}\text { M } & \text { I } & S & \text { C } & \text { E } & \text { L } & \text { L } & \text { A } & \text { N } & \text { E } & \text { A }\end{array}$

\title{
Od iluminatorstwa do grafiki książkowej. Kilka uwag o graficznych pracach Mistrza Collectarium wawelskiego
}

STRESzczenie. Jedną z poważniejszych konsekwencji wynalezienia druku była konieczność przekwalifikowania się wielu osób związanych z produkcją książki rękopiśmiennej. Niniejszy artykuł jest próbą analizy owego problemu, skupioną przede wszystkim na iluminatorach, a konkretnie na jednym - Mistrzu Collectarium wawelskiego. Choć ten anonimowy artysta działający w środowisku krakowskim w pierwszej połowie XVI wieku znany jest najlepiej ze swych dzieł miniatorskich (którym zresztą zawdzięcza przydomek), to równie ciekawe i dobre artystycznie są jego projekty graficzne służące do opracowania klocków drzeworytniczych oraz plakiet introligatorskich. Biorąc zaś pod uwagę fakt, że ilustracje wykonane według jego rysunków zdobiły najlepsze wydawnictwa tamtych czasów, m.in. Chronica Polonorum Miechowity (1519 i 1521) i Contenta de vetustatibus Polonorum Josta Decjusza (1521), warto przyjrzeć się bliżej jego graficznej działalności.

SŁowA KLUCzowe: iluminatorstwo i grafika książkowa 1. połowy XVI wieku, sztuka Krakowa XVI wieku, książka rękopiśmienna i drukowana przełomu XV i XVI wieku.

Przełom, rewolucja, początek nowej ery - tak zwykło się najczęściej określać moment pojawienia się wynalazku Jana Gutenberga, który wszelako niejednemu wydawał się swoistym końcem świata, przynajmniej tego dotychczasowego.

Powiadam wam, panie, że to koniec świata. [...] To te przeklęte dzisiejsze wynalazki gubią ludzkie dusze. Armaty, serpentyny, bombardy, a nade wszystko druk, najgorsza zaraza z Niemiec idąca. Nie ma już manuskryptów, nie ma już ksiąg. Druk zabija księgarstwo ${ }^{1}$.

${ }^{1}$ W. Hugo, Katedra Marii Panny, przeł. H. Szumańska-Grossowa, posłowie Z. Bieńkowski, Szczecin 1991, s. 19. 
Wprawdzie owe dramatyczne słowa padły z ust postaci literackiej - mistrza Andrzeja Musniera, księgarza Uniwersytetu, jednego z bohaterów Katedry Marii Panny w Paryżu Wiktora Hugo, ale nietrudno sobie wyobrazić, że w rzeczywistości pozaliterackiej mogły zostać wypowiedziane przez niejedną osobę będącą świadkiem lub „ofiarą” zmian, jakie wywołał wynalazek wielkiego moguncjanina.

Jedną z najpoważniejszych konsekwencji wynalezienia druku była konieczność przekwalifikowania się wielu osób związanych dotychczas z wytwarzaniem książek rękopiśmiennych. Po wprowadzeniu do użytku prasy drukarskiej oraz metalowych ruchomych czcionek - które umożliwiały powielanie tego samego tekstu w przynajmniej kilkakrotnie większej liczbie egzemplarzy niż wtedy, gdy zadanie to spoczywało (i to dosłownie) w rękach kopistów oraz katedralistów - ci ostatni właśnie w pierwszej kolejności pozbawieni zostali dotychczasowego zajęcia. Podobny los spotkał również stacjonariuszy, czyli ówczesnych licencjonowanych przez władze uniwersyteckie księgarzy i właścicieli skryptoriów zarazem, których zadaniem było wypożyczanie studentom rękopisów do kopiowania, a także ich wytwarzanie i rozprowadzanie we własnym zakresie ${ }^{2}$. Wielu z nich nie umiało pogodzić się z nową sytuacją i nic dziwnego, że do wynalazku Gutenberga odnosili się niezbyt przyjaźnie. Niektórzy - tak jak najsłynniejszy włoski stacjonariusz, florentyńczyk Vespasiano da Bisticci, „,który dla nowej techniki żywił pogardę w rodzaju tej, jaką wytrawny kołodziej żywić może dla pojazdu bez koni, pełen niesmaku porzucił handel książkami, zaszywając się w swej wiejskiej posiadłości, aby tam żyć przeszłością" ${ }^{\prime 3}$ - całkowicie odcinali się od nowinki technicznej i jednocześnie od produkcji książki w ogóle ${ }^{4}$.

Inni reagowali na szczęście mniej radykalnie i starali się odnaleźć swoje miejsce w nowo wykreowanej rzeczywistości. Dostrzegając więc to, co nieuniknione, czyli przegraną ręcznego przepisywania książek w rywalizacji z pisaniem ich w sposób sztuczny (artificialiter scribendi), sami inicjowali przejście na "stronę" typografii. Tak uczynił między innymi kopista Peter Schöffer - znany zresztą dzisiaj o wiele lepiej właśnie jako typograf,

${ }^{2}$ Więcej o zawodzie stacjonariusza zob. E.L. Eisenstein, Rewolucja Gutenberga, przeł. H. Hollender, Warszawa, 2004, s. 11. Zob. również: Encyklopedia wiedzy o książce, red. A. Birkenmajer, B. Kocowski, J. Trzynadlowski, Wrocław 1971, szp. 2208.

${ }^{3}$ P. Burke, Kultura i społeczeństwo w renesansowych Włoszech, przeł. W.K. Siewierski, Warszawa 1991, s. 67.

${ }^{4}$ Dla porównania: gdy pierwsi działający w Italii typografowie - Konrad Sweynheym i Arnold Pannartz - w ciągu pięciu lat wydali (jak się szacuje) 12 tysięcy tomów, to do ich przepisania Vespasiano musiałby zatrudnić w swej pracowni aż tysiąc skrybów (sic!). Ibidem, s. 66-67. 
najpierw czeladnik Jana Gutenberga, a później wspólnik i zięć zarazem Johanna Fusta, z którym wydał np. sławny Psałterz moguncki (1457). Jego śladem podążyli też parający się wcześniej kopiowaniem Domenico de Lapi i Taddeo Crivelli ${ }^{5}$ (będący także iluminatorem) ${ }^{6}$, którzy zasłynęli między innymi z wytłoczenia pięknej edycji Ptolemeuszowego dzieła Cosmographia (Bolonia 1477). W nieco mniejszym zakresie przekwalifikował się z kolei florencki księgarz Zanobi di Mariano, który rozszerzył swoją dotychczasową działalność o sprzedaż odtrąconych z pogardą przez Vespasiana (zresztą swego odwiecznego rywala) ksiąg drukowanych, dzięki czemu utrzymał firmę aż do śmierci (1495), podczas gdy da Bisticci musiał zamknąć swoją już w 1478 roku$^{7}$.

Zupełnie inaczej rzecz miała się $\mathrm{w}$ przypadku iluminatorów, przede wszystkim dlatego, iż zmiany zachodzące za sprawą Gutenbergowskiego wynalazku nie zmusiły ich - przynajmniej początkowo - do przekwalifikowania, ale wręcz do zintensyfikowania pracy. Powszechnie bowiem wiadomo, że pierwsze książki drukowane były bardzo silnie upodabniane do rękopiśmiennych, co przejawiało się zarówno w opracowaniu kroju czcionki na kształt liter pisanych odręcznie, podobnym zaprojektowaniu kolumny i ustaleniu wielkości marginesów ${ }^{8}$, jak i w zdobieniu kart malowaną dekoracją.

Za każdą książką, którą drukował Peter Schoeffer, stoi opublikowany rękopis [...]. Decyzja co do kroju pisma, wybór inicjałów i ornamentacji nagłówków, określenie długości i szerokości kolumny, rozplanowanie marginesów [...] wszystko to było narzucone przez leżący przed nim manuskrypt ${ }^{9}$.

A więc mimo iż zmieniła się technika powielania tekstu, sposób jego dekorowania pozostał w pierwszych latach istnienia typografii identyczny: kolumny okalane były wciąż ręcznie malowanymi floraturami, inicjały wypełniano rozmaitymi, często figuralnymi, kompozycjami, a całość mieniła się wieloma barwami. Pracy iluminatorom nie tylko nie brakowało, ale nawet przybywało, gdyż do wciąż tworzonych manuskryp-

\footnotetext{
${ }^{5}$ Ibidem, s. 67.

${ }^{6}$ Do jednych z najsłynniejszych i najpiękniejszych prac iluminatorskich Crivellego należy Biblia Borso d'Este, wykonana wraz z Franco dei Russi i datowana na lata 1455-1461, a obecnie znajdująca się w zbiorach Biblioteca Estense w Modenie.

${ }^{7}$ E.L. Eisenstein, op.cit., s. 30.

${ }^{8}$ Ibidem, s. 31.

${ }^{9}$ H. Lehmann-Haupt, Peter Schoeffer of Gernsheim and Mainz, Rochester N.Y. 1950, s. 37-38, cyt. za: E.L. Eisenstein, op.cit., s. 31.
} 
tów, których dekorowaniem dotychczas się zajmowali, dołączyły księgi drukowane ${ }^{10}$.

Sytuacja zaczęła się jednak stopniowo zmieniać i - choć nieco później także iluminatorzy stanęli przed koniecznością wyboru innej drogi rozwoju artystycznego, ponieważ ich dotychczasowe zajęcie stawało się powoli nieaktualne. Wraz bowiem ze zdobywaniem coraz silniejszej pozycji na rynku księgarskim w drukach zaczęto coraz wyraźniej zaznaczać odmienność i wprowadzać elementy wcześniej - w rękopisach - niespotykane, takie jak: sygnet drukarski, czyli znak firmowy impresora, karta tytułowa ${ }^{11} \mathrm{i}$ - dla niniejszych rozważań najistotniejsze - odbijane techniką drzeworytową obrazki.

Obrazki te znane były zresztą już wcześniej z książek blokowych, czyli ksylograficznych, popularnych szczególnie w Niemczech i Niderlandach w pierwszej połowie XV stulecia, a z chwilą rozpowszechnienia Gutenbergowskiego wynalazku szybko wypartych z rynku wydawniczego przez książki drukowane ${ }^{12}$. Jak wskazuje Elisabeth Eisenstein:

Nawet jeśli u początków druku ksylograficznego i prasy drukarskiej leżały odrębne wynalazki, wykorzystywane najpierw do innych celów (np. karty do gry i wizerunki świętych były tłoczone z kloców drzeworytniczych, podczas gdy ręczne iluminacje wciąż zdobiły liczne wczesne książki drukowane), obie techniki szybko się splotły. Posługiwanie się typografią przy tekstach prowadziło do zastosowania ksylografii do ilustracji $[\ldots]^{13}$.

Ową pierwszą książką zwiastującą kres świetności sztuki miniatorskiej był w rzeczywistości wielce niepozorny druk, który wytłoczony został 14 lutego 1461 roku w Bambergu ${ }^{14}$. Istotny i zapewne nieprzypadkowy

\footnotetext{
${ }^{10}$ Piękne i obszerne opisy malowanych ręcznie dekoracji zdobiących druki z XV stulecia, które obecnie znajdują się w zbiorach Biblioteki Jagiellońskiej, zamieściła w swej pracy Zofia Ameisenowa (Rękopisy i pierwodruki iluminowane Biblioteki Jagiellońskiej, Wrocław 1958, poz. 146-189, 191-193, s. 129-153, 155-156). Warto zauważyć, że wszystkie wymienione przez badaczkę druki wydane zostały poza granicami Polski, ale ich dekorację malarską wykonano w Krakowie.

${ }^{11}$ K. Krzak-Weiss, Polskie sygnety drukarskie od XV do połowy XVII wieku, Poznań 2006, s. 15-17, 23-25.

${ }^{12}$ Więcej o książkach drzeworytowych, zob.: B. Kocowski, Drzeworytowe ksią̇ki średniowiecza, Wrocław 1975, passim; H. Szwejkowska, Ksiązka drukowana XV-XVIII wieku. Zarys historyczny, wyd. 2 przejrz. i uzup., Wrocław-Warszawa 1975, s. 7-12.

${ }^{13}$ E.L. Eisenstein, op.cit., s. 34.

${ }^{14} \mathrm{~K}$. Krużel, Wśród starych rycin. Wybrane zagadnienia opracowania formalnego dawnej grafiki, Kraków 1999, s. 74.
} 
jest fakt, iż stało się to $\mathrm{w}$ oficynie Albrechta Pfistera ${ }^{15}$ - impresora, ale wcześniej, jak się przypuszcza, kartownika (Briefmaler) ${ }^{16}$, czyli malarza zajmującego się masowym wytwarzaniem przede wszystkim kart do gry i obrazków świętych, a zatem rzemieślnika dobrze obeznanego z techniką drzeworytu, która doskonale sprawdzała się w produkcji tychże obrazków. Ich połączenie z ruchomą czcionka, odbijaną na tej samej, co ksylografy, zasadzie druku wypukłego, było więc dla Pfistera zadaniem wyjątkowo prostym. Pierwszym drukiem, w którym to uczynił, było Der Edelstein Ulricha Bonera. Zebrane w nim bajki o zwierzętach i roślinach ozdobione zostały przez 101 rycin, wielce zresztą prawdopodobne, że autorstwa samego typografa ${ }^{17}$. Ryciny te były bardzo proste, wręcz prymitywne, o silnie zarysowanej kresce konturowej i bez śladów modelunku plastycznego, co najpewniej skłoniło Svenda Dahla do sformułowania tezy, jakoby nie ulegało wątpliwości, iż „na początku ilustracje te pomyślane były tylko jako kontury stanowiące podkład dla malarza, który miał później nakładać na nie farby"18. I rzeczywiście, niejednokrotnie zdarzało się, iż je nakładał, co przemawiałoby na korzyść twierdzenia Dahla. Trudno jednak się z tą koncepcją zgodzić, bo moim zdaniem konturowość owych wczesnych ilustracji wynikała przede wszystkim ze zwyczajnego braku technicznej biegłości, zaś ich późniejsze kolorowanie miało to nieco zatuszować i tym samym podwyższyć walory artystyczne wyposażenia graficznego oraz podnieść wartość całego druku. Niewykluczone też, iż miało to na celu zachowanie ostatniej, subtelnej nici wiążącej książkę już w pełni tłoczoną z jej iluminowaną rękopiśmienną poprzedniczką. Gdyby bowiem racja była po stronie Dahla i konturowe ryciny byłyby w istocie formami do kolorowania, to barwne byłyby wszystkie edycje zdobione drzeworytami, a przynajmniej większość z nich. Tymczasem proporcje są wyraźnie odwrotne i więcej jest wersji czarno-białych niż, jak można przyjąć, luksusowych - kolorowych. I choć z czasem owych kolorowanych druków

${ }^{15}$ S. Dahl, Dzieje książki, przeł. E. Garbacik, T. Zapiór, H. Devechy, Wrocław 1965, s. $129-130$.

16 ,Kartownikiem jest artysta umiejący wykonać karty z usztywnionego i specjalnie zgiętego papieru, na które nanosi obrazy albo inne znaki w określonej ilości dla zabawy chłopców, [a czyni to - K.K.W.] dokładnie malując ręcznie albo za pomocą szablonów do tego przygotowanych" - taka definicja zawodu kartownika znajduje się w rękopisie Pawła Paulirinusa Viginti atrium liber (1460), należącym do zbiorów Biblioteki Jagiellońskiej w Krakowie. Zob. B. Kocowski, op.cit., s. 30. Pierwszy polski kartownik, którym był Hanusz z Bolesławia, odnotowany zostałźródłach archiwalnych w roku 1499. Zob. T. Seweryn, Staropolska grafika ludowa, Warszawa 1956, s. 11.

${ }^{17}$ Jeden z zachowanych egzemplarzy tego druku znajduje się obecnie w zbiorach Herzog-August-Bibliothek w Wolfenbüttel.

${ }^{18}$ S. Dahl, op.cit., s. 9. 
było coraz mniej, bo drzeworyt konturowy ustąpił miejsca bardziej plastycznemu, który przez wykorzystanie szrafowania (czyli kreskowania) ${ }^{19}$ wprowadzał obok czerni farby drukarskiej całą gamę szarości - to jeszcze długo iluminatorom pracy nie brakowało.

Konieczne jest bowiem zaznaczenie, że wytłoczenie pierwszej książki zdobionej ksylografami nie oznaczało natychmiastowego odejścia od dekoracji iluminowanej, tak zresztą jak pojawienie się druków nie spowodowało nagłego zaniku rękopisów. Jak zauważa Barbara Bieńkowska, „rękopis nie przestał automatycznie stanowić integralnego komponentu kultury umysłowej i artystycznej, lecz współistniał z drukiem początkowo na zasadzie rywalizacji, a później dopełnienia w tych dziedzinach, którym nowa technika nie zdołała w pełni sprostać" ${ }^{20}$. W wielu zatem ośrodkach przez długi czas doskonale funkcjonowały obie metody wytwarzania oraz zdobienia książek i miało to miejsce nawet wówczas, gdy pozycja sztuki drukarskiej i zdobiących ją drzeworytowych ilustracji była już bardzo silna. Najlepszym tego dowodem jest środowisko krakowskie, w którym najwybitniejsze osiągnięcia sztuki iluminatorskiej, szczególnie w postaci prac Stanisława Samostrzelnika, powstały w latach 20. i 30. XVI wieku' ${ }^{21}$, kiedy to w Krakowie działało już całkiem sporo - i to świetnie radzących sobie - oficyn ${ }^{22}$. Zresztą przykład brata z Mogiły nie jest wcale odosobniony. Znakomite dzieła sztuki iluminatorskiej z tego czasu powstawały też w środowiskach: włoskim, niderlandzkim, francuskim czy węgierskim ${ }^{23}$. Warto również zaznaczyć, iż malarstwo książkowe w Polsce kontynuo-

\footnotetext{
${ }^{19}$ Szrafowanie polega na cieniowaniu ryciny przez zastosowanie równoległych lub krzyżujących się linii. Zob. Słownik terminologiczny sztuk pięknych, red. S. Kozakiewicz, Warszawa 1969, s. 339. Jako pierwszy posłużył się nim Erhard Reuwich - autor znakomitych ilustracji do Peregrinatio in Terram Sanctam Bernarda von Breydenbacha (Moguncja 1486).

${ }^{20}$ B. Bieńkowska, Wstęp, w: Książka rękopiśmienna XV-XVII w., red. B. Bieńkowska, Warszawa 1980, s. 6.

${ }^{21}$ Więcej o Samostrzelniku, jego pracach i warsztacie, zob. m.in.: B. Miodońska, Miniatury Stanisława Samostrzelnika, Warszawa 1983; eadem, Małopolskie malarstwo książkowe 1320-1540, Warszawa 1993, passim; eadem, Świat malarski Stanisława Samostrzelnika. Miniatury, „Cistercium Mater Nostra” 2007, s. 63-78.

${ }^{22}$ B. Bieńkowska, Staropolski świat ksiażek, Wrocław 1976, s. 36-37.

${ }^{23}$ Dość wspomnieć przepiękny flandryjski Brewiarz Grimaniego datowany na lata 1490-1510, którego iluminacje przypisuje się pracowni Hansa Memlinga oraz Aleksandrowi i Simonowi Beningom (obecnie w zbiorach Biblioteca Nazionale Marciana w Wenecji). Zob. K. Csapodi-Gárdonyi, Iluminowane kodeksy europejskie, Wrocław 1984, poz. 52-53. Na wzmiankę zasługują też wyróżniające się wspaniałą dekoracją malarską Godzinki Farnese, zdobione przez Giulio Clovio, a datowane na lata 1538-1546 (Pierpont Morgan Library, New York), oraz Godzinki ze zbiorów Walters Art Museum w Baltimore, powstałe w 1524 roku, a iluminowane przez Jeana de Mauléona.
} 
wane było nawet w XVIII stuleciu, choć jego charakter był już wówczas całkowicie inny i stanowi ono odrębne zagadnienie badawcze ${ }^{24}$.

Nie ulega jednak wątpliwości, że właśnie koniec XV i początek XVI wieku były dla iluminatorów czasem największej próby. Próby, która sprawiła, że wielu z nich porzuciło pierwotne zajęcie i, idąc z duchem czasu, zajęło się tworzeniem rysunkowych projektów służących za podstawę do wykonania klocków drzeworytowych, a niekiedy także plakiet introligatorskich. Niektórzy działali na obu polach artystycznych (tj. miniatorskim i graficznym) jednocześnie. Do ostatnich należał między innymi anonimowy artysta krakowski, który przez wybitną badaczkę miniatorstwa polskiego - Barbarę Miodońską - określony został mianem Mistrza Collectarium wawelskiego ${ }^{25}$. Przydomek ten zawdzięczał wykonaniu bogatej dekoracji iluminatorskiej kolektarza przeznaczonego na użytek katedry wawelskiej $^{26}$, powstałego przed 1526 rokiem $^{27}$. Nie była to jedyna praca miniatorska tego artysty, zdaniem Miodońskiej mistrz ów był bowiem na pewno autorem dekoracji do: ksiąg muzycznych krakowskich dominikanów (Communale solenne z 1522 roku i Antyfonarza z lat 1515-1523; przy obu współpracował z Iluminatorem Kodeksów Łaskiego), Graduale de tempore et de sanctis zamówionego w 1526 roku przez Annę Grabowską (przełożoną klasztoru norbertanek na Zwierzyńcu), a także iluminacji do druków, o czym świadczy egzemplarz Mszału krakowskiego (1515-1516) wydanego przez Jana Hallera, należący kiedyś do Jana Szykowskiego. Ponadto pewne podobieństwa wskazuja, iż mógł iluminować także księgi

${ }^{24}$ B. Bieńkowska, Staropolski świat..., s. 37-38. Z powstałych po XVI stuleciu przykładów polskiego iluminatorstwa warto wymienić prace Błażeja Dereja z Siewierza: antyfonarz dla konwentu przemyskiego (1627), mszał dla klasztoru w Piotrkowie (1630), graduał dla tamtejszych dominikanek (1632-1635), psałterz z 1661 roku oraz graduał dla klasztoru w Łucku (1642). Zob. Zabytki sztuki w Polsce, t. 2: Iluminowane rękopisy księgozbioru oo. dominikanów i oo. karmelitów Krakowie, oprac. F. Kopera, L. Lepszy, Kraków 1926. Warto wspomnieć również o antyfonarzu powstałym w Lublinie najpewniej dla klarysek, a iluminowanym przez o. Hipolita Szolca (1680). Zob. Z. Ameisenowa, op.cit., poz. 200, s. 174-177. Odrębną grupę prac iluminowanych stanowią uniwersyteckie księgi promocyjne i wykładowe Uniwersytetu Jagiellońskiego, z których zachowało się sześć prowadzonych od połowy XVI do połowy XVIII wieku. Zob. E. Chojecka, Dekoracja malarska ksiag promotionum i diligentiarum Uniwersytetu Jagiellońskiego XVI-XVIII wieku, Kraków 1965.

${ }^{25}$ B. Miodońska, Małopolskie malarstwo..., s. 152-154, 190-191.

${ }^{26}$ Kolektarz ten omówiony został szczegółowo w wydanej niedawno monografii opracowanej przez księdza Szymona Fedorowicza (Kolektarz wawelski sprzed 1526 roku. Świadek liturgii Kościoła krakowskiego w XV, XVI i XVII wieku, oprac., edycja X. S. Fedorowicz, Karków 2007).

${ }^{27}$ Obecnie Collectarium wawelskie przechowywane jest w Archiwum i Bibliotece Krakowskiej Kapituły Katedralnej (sygnatura AKK KP 57). 
liturgiczne bernardynów krakowskich i kielecki Antyfonarz de sanctis ${ }^{28}$. Pozostawiając jednak na uboczu niniejszych zainteresowań malarskie dzieła anonimowego mistrza, omówione już zresztą wyczerpująco przez Miodońska, zamierzam przyjrzeć się bliżej jego pracom graficznym. Nie doczekały się one dotąd wnikliwszej analizy, mimo że na pewno na nią zasługuja, choćby z uwagi na swą niepoślednią - jak na poziom ówczesnej polskiej grafiki ilustracyjnej - jakość.

Przed przystąpieniem do analizy konieczne jest dokładne ustalenie, które drzeworytowe ilustracje wykonane zostały według projektów Mistrza Collectarium wawelskiego. Wcześniej trzeba uściślić, że w przypadku tego artysty rozpatrywać należy właśnie autorstwo projektów do drzeworytów, a nie wykonanie samych drzeworytniczych klocków, bo są to dwa różne zakresy działań ${ }^{29}$. Wydaje się zaś raczej mało prawdopodobne, by mistrz sztuki miniatorskiej zdołał przekwalifikować się tak bardzo, żeby opanować niezwykle trudne arkana techniki drzeworytowej. Cięcie w drewnie było bowiem bliższe snycerstwu niż malarstwu i wymagało całkiem innych umiejętności ${ }^{30}$. Ich brak nie oznaczał jednak dla artysty malarza niemożności współtworzenia prac graficznych.

Wiadomo, że już od drugiej połowy XV stulecia istniał zawód Formschneidera, czyli wykrawacza form ${ }^{31}$, który świetnie władając rylcem i dłutem, zajmował się właśnie wycinaniem w deskach drewnianych cudzych kompozycji i w ten sposób - tworzeniem gotowych do odbicia klocków. Oznaczało to, że na ostateczny kształt ryciny mogły wpływać dwie, a w skrajnych przypadkach nawet trzy osoby (projektant, Formschneider i malarz kolorujący rycinę, jeśli ta miała być kolorowa) ${ }^{32}$, ale także to, iż wówczas gdy artysta nie potrafił wyciąć w drewnianej deseczce stworzonej przez siebie kompozycji, mógł się posiłkować rytownikiem, który uczynił to za niego. Niestety obecnie rozróżnienie, które z rycin wykonane zostały od początku do końca - czyli od fazy projektu do gotowego klocka przez jednego mistrza, a w których tworzeniu brało udział dwóch, jest właściwie niemożliwe, jeśli na grafikach nie zachowały się żadne sygna-

\footnotetext{
${ }^{28}$ B. Miodońska, Małopolskie malarstwo..., s. 190.

${ }^{29}$ Wartotoostateczniedoprecyzować, bochoćby wspominającaoprzekwalifikowaniu Mistrza Collectarium wawelskiego Miodońska raz pisze o tym, jakoby był on tylko projektantem (ibidem, s. 154, 190), a innym razem - rytownikiem (s. 33, 152).

${ }^{30}$ Zdaniem Tadeusza Seweryna drzeworytnictwem zajmowali się więc rzezacze pieczęci i dekoratorzy herbów oraz kartownicy (op.cit., s. 11).

${ }^{31}$ M. Bóbr, Mistrzowie grafiki europejskiej od XV do XVIII wieku, Warszawa 2000, s. 13; K. Krzak-Weiss, Polskie sygnety..., s. 27.

${ }^{32}$ K. Krużel, op.cit., s. 19.
} 
tury ani nie istnieją źródła archiwalne opisujące ich powstanie ${ }^{33}$. Ponieważ tak właśnie jest w przypadku Mistrza Collectarium wawelskiego, pozostaje tylko przypuszczać, że był on jedynie projektantem prac graficznych, które następnie wykrawał ktoś inny. Przyjmując zatem owo zastrzeżenie, do projektów anonimowego mistrza zaliczyć można: drzewo genealogiczne Jagiellonów odbite w Contenta de vetustatibus Polonorum Josta Decjusza (Kraków, Hieronim Wietor 1521, zob. il. 1) ${ }^{34}$ oraz wizerunek św. Stanisława (używany przez Wietora w latach 1519 i 1521, zob. il. 2) - przypisane mu przez Miodońską ${ }^{35}$. A ponieważ druga z tych prac - jak ustaliła Maria Krynicka - posłużyła później za wzór do wykonania metalowej plakiety introligatorskiej używanej w warsztacie Mistrza Główek Anielskich ${ }^{36}$, to za dzieła Mistrza Collectarium uznaje się także inne tego typu projekty, m.in. te, na podstawie których wykonano plakiety dla warsztatu Mistrza Medalionów ${ }^{37}$. Z kolei według moich ustaleń do dzieł anonimowego mistrza zaliczyć można również projekty do: sygnetów drukarskich Floriana Unglera z wyobrażeniem św. Floriana (1515) i Hieronima Wietora z przedstawieniem antycznego bóstwa granic - Terminusa (1523-1526), ilustracji Koronacja Bolestawa Chrobrego przez cesarza Ottona III z Chronica Polonorum Macieja z Miechowa (Wietor 1519 i 1521) ${ }^{38}$ oraz blisko połowy spośród ilustracji zdobiących łacińską edycję modlitewnika Hortulus animae, który wydany został przez Macieja Szarfenberga w 1533 roku (il. 3) $)^{39}$.

${ }^{33}$ Ryciny, na których umieszczone zostały sygnatury ich Formschneiderów, należą do
rzadkości. Takim przypadkiem jest m.in. drzeworytowy portret Filipa Melanchtona,
który został wykonany według projektu Łukasza Cranacha Młodszego, a umieszczo-
na na nim niemal niewidoczna sygnatura informuje, iż za wycięcie klocka odpowiada
Jacob Lucius (ibidem, s. 19-20). Sygnatura rytownika zachowała się także na sygne-
cie drukarskim strasburskiego impresora Theodosiusa Rihela, który zaprojektowany
został przez Tobiasa Stimmera, ale wycięty przez Bernarda Jobina (K. Krzak-Weiss,
Polskie sygnety..., s. 27).
${ }^{34}$ Obszerny opis ryciny z drzewem genealogicznym Jagiellonów umieściła w swej
pracy Antonina Betterówna, nie identyfikującjednak jej autora z Mistrzem Collectarium
wawelskiego. Zob. A. Betterówna, Polskie ilustracje ksiażkowe XV i XVI w. (1490-1525),
Lwów 1929, s. 378.

${ }^{35}$ B. Miodońska, Małopolskie malarstwo..., s. 152, 190.

${ }^{36}$ M. Krynicka, Elementy figuralne dekoracji polskich opraw ksiażkowych $i$ ich zwiazki $z$ grafika w pierwszym trzydziestoleciu XVI wieku, w: Dawna ksiażka i kultura. Materiaty międzynarodowej sesji naukowej z okazji pięćsetlecia sztuki drukarskiej w Polsce, red. S. Grzeszczuk, A. Kawecka-Gryczowa, Wrocław 1975, s. 179-181.

${ }^{37}$ Ibidem, s. 172-183. Tam również więcej o działalności obu warsztatów introligatorskich.

${ }^{38}$ K. Krzak-Weiss, Polskie sygnety..., s. 67-68, 111, 118-119.

${ }^{39} \mathrm{~K}$. Krzak-Weiss, O chronologizacyjnych możliwościach tkwiacych w drzeworycie z wizerunkiem św. Jerzego w polskich "Hortulusach" pierwszej połowy XVI wieku, "Roczniki 
Podstawą każdej z tych atrybucji była wnikliwa analiza stylistyczno-porównawcza. Obierając za punkt wyjścia prace iluminatorskie Mistrza Collectarium wawelskiego i ich najbardziej charakterystyczne cechy, takich samych poszukiwano w pracach graficznych. Jakie to były cechy? Przede wszystkim mocno zaakcentowana kreska konturowa, wyraziście zarysowująca poszczególne elementy kompozycji, która z kolei odznaczała się oszczędnością i czytelnością. Poza tym: specyficzny sposób przedstawiania postaci o krępych, przysadzistych sylwetkach, twarzach wprawdzie ładnych, ale nieco bez wyrazu, przykuwających uwage jedynie sposobem przedstawienia oczu - mocno zaakcentowanych, dużych, o ciężkich, opadających powiekach. Typowe dla Mistrza Collectarium jest także umieszczanie w pejzażowym tle - silnie zresztą zredukowanym - pojedynczych, lub połączonych w kępki, suchych gałązek. Ponadto, zarówno w pracach iluminatorskich krakowskiego artysty, jak i w jego projektach do drzeworytów wyraźnie zauważalne jest czerpanie inspiracji z niemieckiego środowiska artystycznego, konkretnie zaś z twórczości Albrechta Altdorfera, Albrechta Dürera, Hansa Schäufeleina, oraz Hansa Springinkleego ${ }^{40}$. Korzystając z tak znakomitych wzorów - bardzo popularnych wówczas w środowisku krakowskim - Mistrz Collectarium często przetwarzał je na swój sposób, który polegał przede wszystkim na znacznej redukcji tła, aż do uzyskania niemal pustej przestrzeni ${ }^{41}$. Taki zabieg zastosował między innymi w projekcie do ryciny przedstawiającej św. Jerzego walczącego ze smokiem, która weszła w skład zespołu ilustracyjnego modlitewnika Hortulus animae $e^{42}$.

Jeszcze ciekawszemu i dalej idącemu przekształceniu krakowski artysta poddał wzorzec w postaci ryciny przedstawiającej króla Dawida podglądającego kąpiącą się Betsabee autorstwa Hansa Springinkleego. Nie tylko bowiem w swojej wersji wszystkie elementy kompozycji znacznie uprościł i pozbawił obecnych w pierwowzorze lekkości i subtelności, ale

Biblioteczne" 53, 2009, s. 122-123. Wśród ilustracji, do których z dużym prawdopodobieństwem projekty wykonał Mistrz Collectarium, należą m.in.: wyobrażenie św. Jerzego, św. Weroniki, Ojców Kościoła z symbolami Ewangelistów, scena z królem Dawidem podglądającym kąpiącą się Betsabee, przedstawienie Ukrzyżowania z Marią i św. Janem oraz Madonny z Dzieciątkiem na półksiężycu.

${ }^{40}$ Mistrz Collectarium korzystał z wzorów niemieckich już w swych pracach iluminatorskich, o czym szerzej pisze Barbara Miodońska (Małopolskie malarstwo..., s. 167). Czerpanie inspiracji z kręgu zachodniego było zresztą wówczas na porządku dziennym i widać tego dowody w większości prac miniatorskich oraz graficznych powstałych wtedy w Krakowie. Więcej o tym zjawisku zob. A.M. Olszewski, Pierwowzory graficzne późnogotyckiej sztuki małopolskiej, Wrocław 1975, passim.

${ }^{41}$ K. Krzak-Weiss, O chronologizacyjnych..., s. 123.

${ }^{42}$ Ibidem, s. 119. 
Olegarduspater Vladiflaus Ia Hedui Anna Elifabet Sophis
la.Dux Lithna gelloPo.Rex gis con con, côiunx. coniüx,

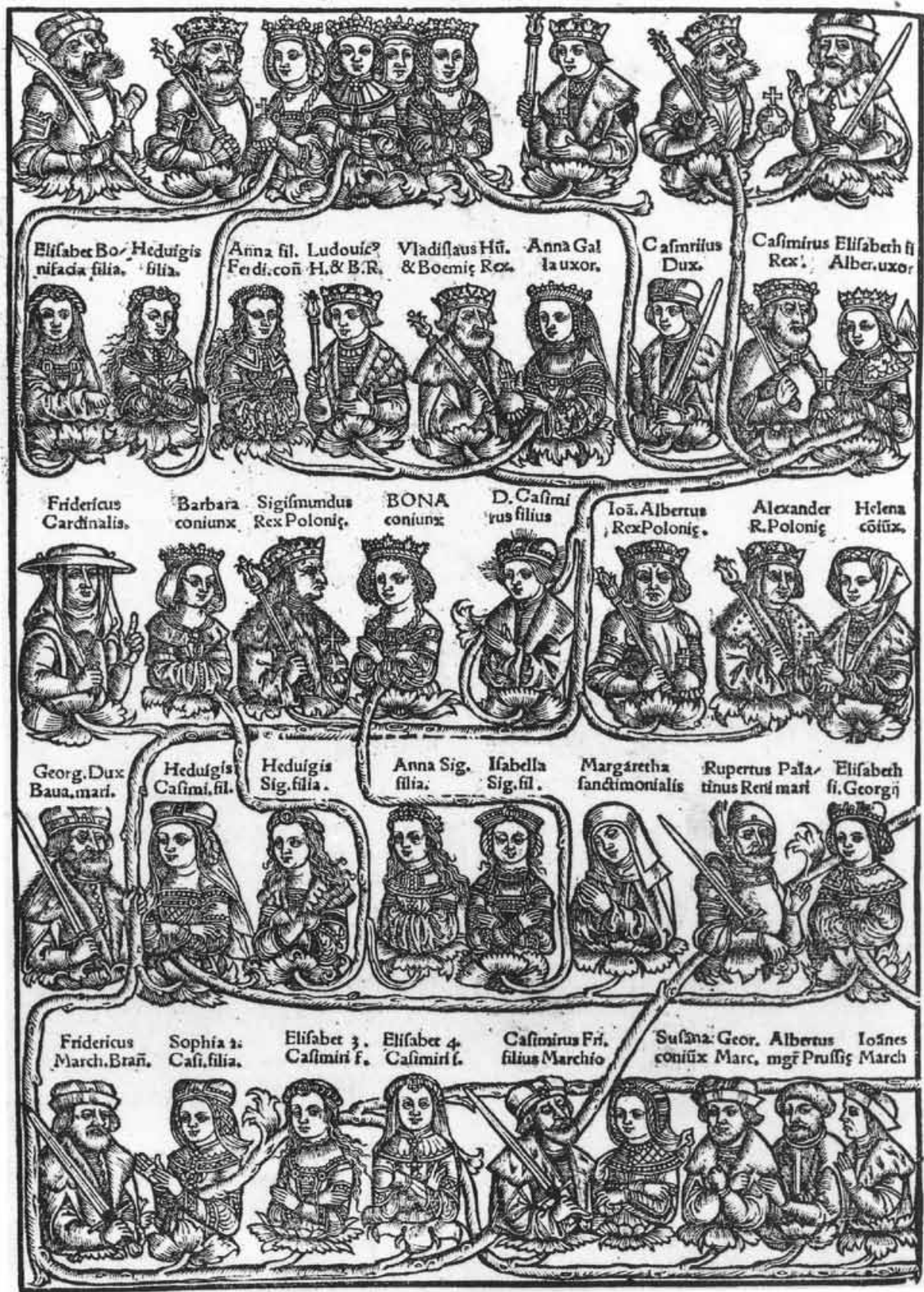

Il. 1. Drzewo genealogiczne Jagiellonów z Contenta de vetustatibus Polonorum Josta Decjusza (Kraków, Hieronim Wietor 1521) 


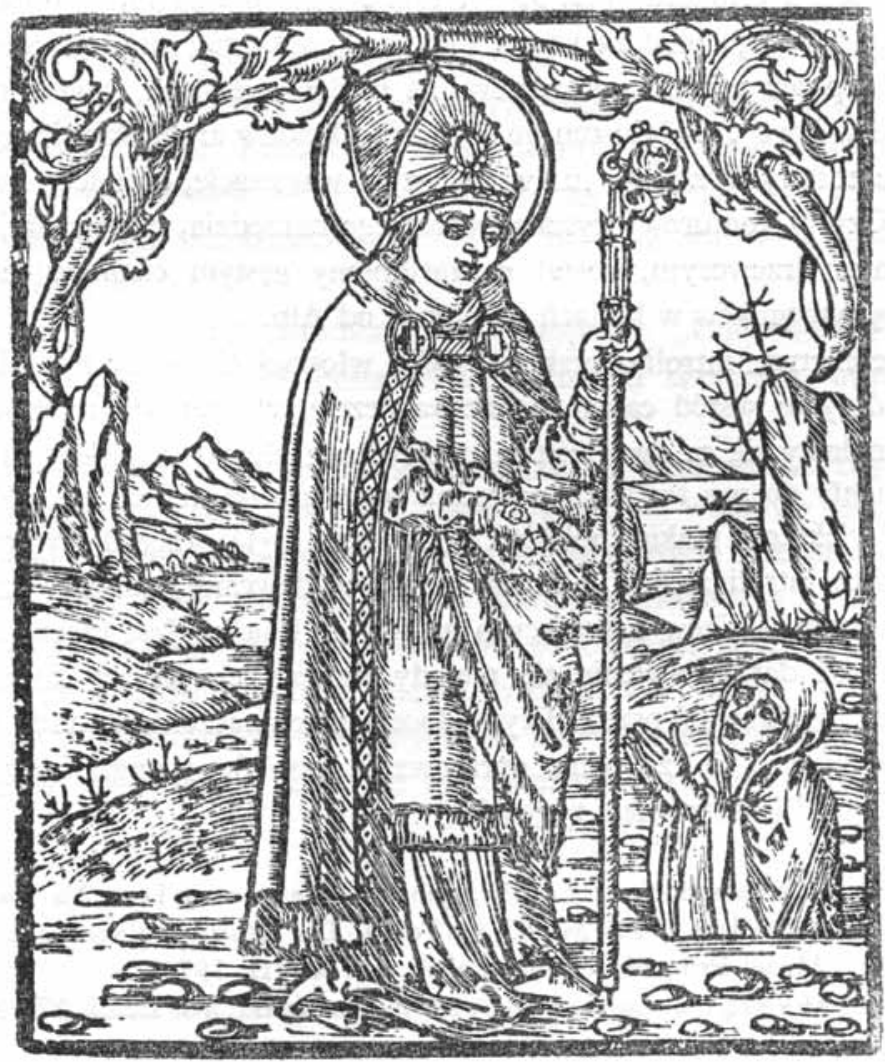

Il. 2. Św. Stanisław z Hymnu o św. Stanisławie Rudolfa Agricoli (Kraków, Hieronim Wietor 1519)

także „ocenzurował" nagą Betsabee, starannie ją odziewając ${ }^{43}$. Co więcej, tworząc kompozycję z Dawidem, Mistrz Collectarium zastosował zwierciadlane odbicie, co jest o tyle zaskakujące, że w innych swoich projektach opartych na cudzych kompozycjach zawsze powielał oryginalne ujęcia. Niezależnie od powodów przyjęcia takiego układu kompozycyjnego zarówno projekt z Betsabee, jak i inne dowodza, że Mistrz Collectarium wawelskiego był twórcą świetnie zorientowanym w najnowszych tendencjach artystycznych i umiejętnie, w pełni świadomie, a nie niewolniczo, korzystającym z dorobku innych, znamienitszych artystów.

Można zatem tylko żałować, że mistrz tej klasy nadal pozostaje anonimowy. Wprawdzie Krynicka sugerowała, by identyfikować go z Piotrem

\footnotetext{
${ }^{43}$ A. Karłowska-Kamzowa, Obrazowa świadomość religijna w późnośredniowiecznych modlitewnikach drukowanych, „Liturgia Sacra” 1995, nr 3/4, s. 201.
} 


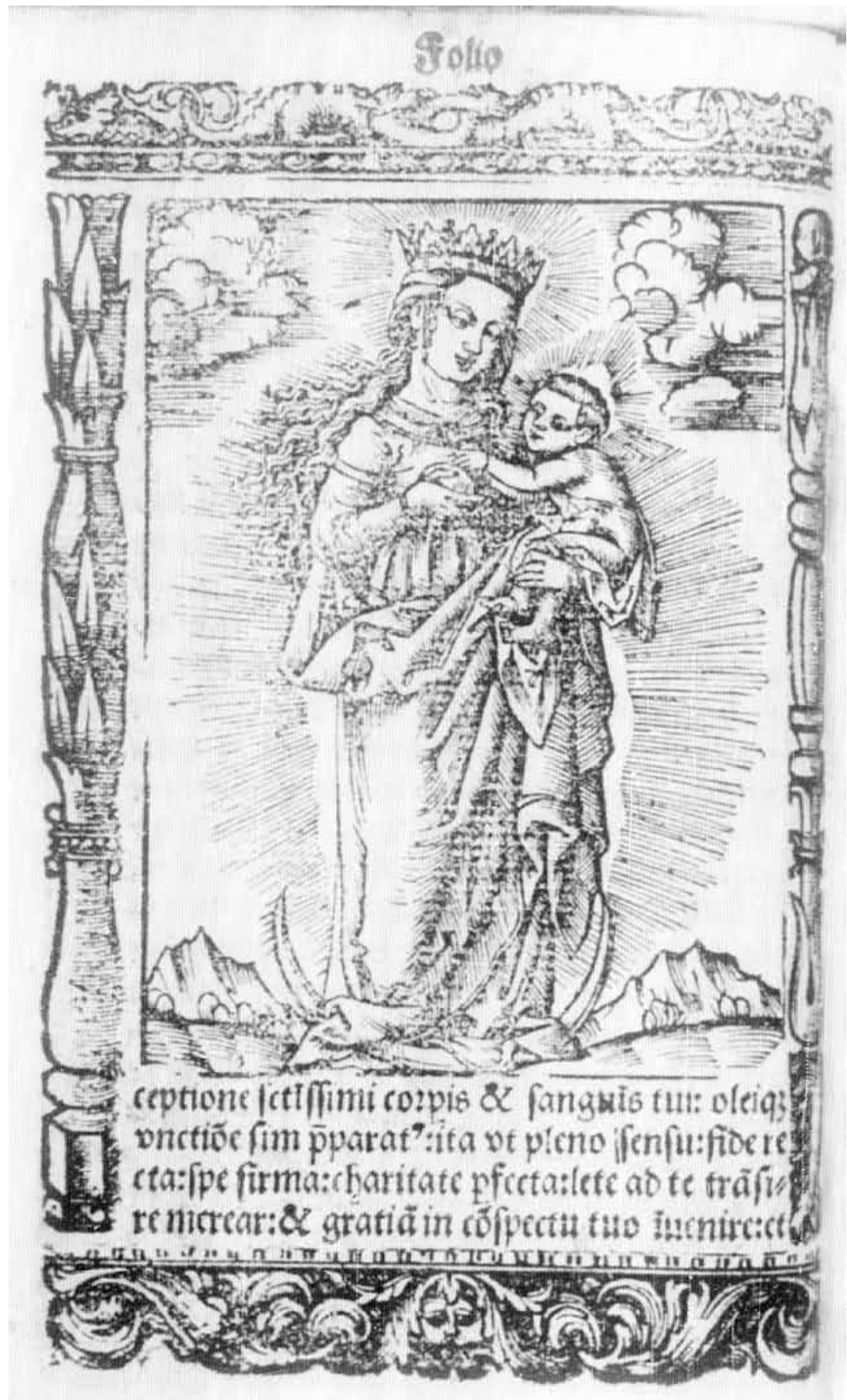

Il. 3. Madonna z Dzieciątkiem na półksiężycu z łacińskiej edycji modlitewnika Hortulus animae (Kraków, Maciej Szarfenberg 1533) 
Postawą z Proszowic - skryptorem i introligatorem (a według niej też iluminatorem $)^{44}$, ale wydaje się to hipotezą raczej mało prawdopodobną. Szczególnie że, jak zauważa Miodońska, „brak podstaw źródłowych nie pozwala uważać go również za iluminatora" ${ }^{45}$. Jej zdaniem warto natomiast zwrócić uwagę na bliski związek prac Mistrza Collectarium i Mistrza Pasji dominikańskiej - autora iluminacji do Rozmyślań dominikańskich ${ }^{46}$, który rzeczywiście niejednokrotnie widoczny jest bardzo wyraźnie, ale który jedynie może, a nie musi przesądzać o identyczności twórców. Równie możliwe jest bowiem, że „iluminacje reprezentują jedynie odmienne «modusy» wykonawcze wynikające z różnicy zadań artystycznych, jakie stanęły przed tym samym iluminatorem" ${ }^{\prime 4}$, jak i to, że były dziełem dwóch bliskich stylem artystów. Niestety wobec braku materiałów źródłowych zapewne nigdy nie poznamy personaliów Mistrza Collectarium, który na zawsze pozostanie ukryty pod przydomkiem.

O wiele łatwiej będzie natomiast ustalić, dla kogo artysta ów pracował i na jakie lata przypadła jego graficzna działalność. Z dotąd przypisanych anonimowemu mistrzowi projektów graficznych widać bowiem wyraźnie, że zdecydowaną większość stanowią wśród nich prace wykorzystywane przez oficynę Hieronima Wietora. To w niej użyto między innymi monumentalnej kompozycji z drzewem genealogicznym Jagiellonów, wyobrażenia św. Stanisława czy - jak można tylko przypuszczać, bo nie zachował się żaden kompletny egzemplarz z tej oficyny - wielu ilustracji do Hortulusa ${ }^{48}$. Być może prac tych było nawet więcej, ale niestety brak pełnego opracowania poświęconego zasobom typograficznym Wietorowskiej oficyny uniemożliwia bardziej precyzyjne ustalenia. Pewne jest natomiast, że Mistrz Collectarium zaopatrywał w swoje projekty warsztat nie tylko Hieronima, ale także Floriana Unglera (kompozycja sygnetowa) i Macieja Szarfenberga (ilustracje hortulusowe), choć w przypadku tego ostatniego istnieje spore prawdopodobieństwo, że materiał ilustracyjny zdradzający autorstwo mistrza przejął on od Wietora. Odsprzedawanie lub wypożyczanie niewykorzystywanych w danej chwili klocków było bowiem wówczas bardzo często praktykowane, a świadectw takich wymian handlowych prowadzonych między tłoczniami Maciejową i Hieronimową znaleźć można wiele ${ }^{49}$. Zważywszy na to, można zaryzykować

\footnotetext{
${ }^{44}$ M. Krynicka, op.cit., s. 183.

${ }^{45}$ B. Miodońska, Małopolskie malarstwo.., s. 83.

${ }^{46}$ Ibidem, s. 191.

${ }^{47}$ Ibidem.

${ }^{48}$ K. Krzak-Weiss, O chronologizacyjnych..., s. 125-127.

${ }^{49}$ A. Kawecka-Gryczowa, A. Mańkowska, Maciej Szarfenberg, w: Drukarze dawnej Polski od XV do XVIII wieku, t. 1: Małopolska, cz. 1: Wiek XV-XVI, red. A. Kawecka-
} 
przypuszczenie, że Mistrz Collectarium pracował w rzeczywistości tylko na rzecz jednej - Wietorowskiej oficyny, z której później jego prace przenikały do innych krakowskich warsztatów. Biorąc zaś pod uwagę daty wydania dzieł, które ozdobione zostały drzeworytami wykonanymi według jego projektów, należałoby przyjąć, że pracę na rzecz Hieronimowej tłoczni podjął około 1518 roku. Pierwsze druki, w których znalazły się drzeworyty jego projektu, pochodzą wprawdzie z 1519 roku (Rudolf Agricola, Hymn o św. Stanisławie oraz Maciej z Miechowa, Chronica Polonorum), ale uwzględniając długość cyklu produkcyjnego zarówno samej książki, jak i ryciny, należy od tej daty odjąć przynajmniej rok. Zdecydowanie trudniej określić terminus ante quem, bo żywotność klocka drzeworytowego była na tyle długa, że mógł on zostać użyty już dawno po zaniechaniu przez Mistrza Collectarium wawelskiego dalszego projektowania graficznego. Daty te, choć bardzo mało precyzyjne, nasuwają jeden ważny wniosek, mianowicie taki, że w przypadku Mistrza Collectarium działalność iluminatorska płynnie przeplatała się z graficzną oraz że krakowski artysta nie tylko nie obawiał się Gutenbergowskiego wynalazku, ale też potrafił doskonale odnaleźć się w rzeczywistości, którą ten tak silnie przeobrażał.

Katarzyna Krzak-Weiss

From illuminating books to printmaking. Some
remarks on the graphic art works of Master of the
Collectarium from the Wawel Castle (a case study)

Авstract. One of the major consequences following the invention and the introduction of movable type printing was the necessity of retraining of a number of people who had been formerly involved in manuscript and incunabula production and dissemination. This article attempts to analyse the issue of introducing this set of new skills, limiting its scope, however, to illuminators only, or, to be more specific, to one exemplary illuminator - the Master of the Wawel Collectarium. Though this anonymous Cracow-based artist from the first half of the sixteenth century is best known from his illuminating works, also his graphic designs for woodblock prints and metal relief plaque bindings are interesting and artistically accomplished. Taking into account the fact that the most illustrious publications of the time were decorated with

-Gryczowa, Wrocław 1983, s. 248; A. Kawecka-Gryczowa, A. Mańkowska, Hieronim Wietor, w: Drukarze dawnej Polski..., s. 347. 
the illustrations made after his drawings (Chronica Polonorum by Maciej Miechowita (Matiae de Mechovia, 1519-1521) and Contenta de vetustatibus Polonorum by Jodocus Lodovicus Decius (1521), it seems absolutely reasonable and worthwhile to investigate his graphic art works activity more thoroughly.

KEY wORDs: illuminated books, graphic art work of the first half of the $16^{\text {th }}$ c., manuscript and printed book at the turn of the $16^{\text {th }} \mathrm{c}$. 